\title{
Feed-out rate used as a tool to manage the aerobic deterioration of corn silages in tropical and temperate climates
}

\author{
T. F. Bernardes, ${ }^{1} \oplus$ I. L. De Oliveira, ${ }^{1}$ D. R. Casagrande, ${ }^{1}$ F. Ferrero, ${ }^{2} \odot$ E. Tabacco, ${ }^{2} \odot$ and G. Borreani ${ }^{2 *} \odot$ \\ ${ }^{1}$ Department of Animal Science, University of Lavras, Lavras, Minas Gerais, 37200-000, Brazil \\ ${ }^{2}$ Department of Agricultural, Forest, and Food Sciences (DISAFA), University of Turin, 10095 Grugliasco, Italy
}

\begin{abstract}
There is an increasing recognition throughout the world that many of the feeding problems of dairy herds are linked to the presence of aerobically deteriorated parts on a silo face, causing farmers to pose questions on what amount of silage should be removed daily to feed their animals. Since an adequate feed-out rate helps to prevent silage spoilage, a simple tool is needed to manage the aerobic deterioration of corn silages during feed-out. The aims of this study were to develop an unloading rate index, which we have called the mass feedout rate (MFR), expressed in kilograms of fresh matter silage unloaded daily per square meter of silo face, to better predict the aerobic deterioration of silage and to offer management solutions to help prevent spoilage, through a survey on 97 commercial dairy farms in Italy and Brazil. Silages were sampled and analyzed for their main microbial, fermentative, and nutritional characteristics, whereas silage temperatures were measured in the core and peripheral areas of the silo working face. Moreover, a detailed questionnaire on silo management and silage utilization was administered to the farmers during each farm visit. The size and silage density of the silos presented a wide variability in the 2 countries, thus indicating that different management practices were adopted during corn harvesting, silo filling, and silage compaction. The differences between $\mathrm{pH}$ and temperature in the peripheral areas and in the core of the silage ( $\mathrm{dpH}$ and $\mathrm{dT}$, respectively) were tested as a single indicator to identify any aerobic deteriorated areas on the silo face, associated with the yeast and mold counts. Both indicators correctly identified aerobic deterioration in $86.6 \%$ and $93.8 \%$ of the studied silos, respectively. The lactic acid and ethanol increased as the MFR increased, whereas the starch, dT, and the yeast and mold counts decreased with increasing MFR. A daily removal rate of over $250 \mathrm{~kg}$ of silage $/ \mathrm{m}^{2}$ markedly
\end{abstract}

Received March 8, 2021

Accepted June 1, 2021.

*Corresponding author: giorgio.borreani@unito.it reduced the risk of spoilage in corn silages at a farm level in both temperate and tropical environments. The new MFR index can substitute for the commonly used linear feed-out rate as it includes the silage density and can be obtained from 1 single recording.

Key words: silage feed-out rate, aerobic deterioration, silage $\mathrm{pH}$, silage temperature

\section{INTRODUCTION}

Whole-plant corn silage accounts for 40 to $50 \%$ of the diet of lactating dairy cows on the arable land of intensive farms in Europe and America (Wilkinson and Toivonen, 2003), and when spoiled silage is fed there is a reduction in animal performance (Ogunade et al., 2018). To obtain a high-quality silage, it is crucial to correctly manage the ensiling process from crop harvesting to silage feeding-out. However, there is an increasing recognition that many of the problems associated with feeding corn silage on dairy farms arise during the unloading phase (Wilkinson and Davies, 2013). Feeding animals with a uniform high-quality silage over the whole profile of the silo for the entire year is crucial to maximize the efficiency and sustainability of livestock farms (Borreani et al., 2018). The key factors that affect silage quality at feeding are the exclusion of oxygen during conservation, the fermentation profile, the daily feed-out rate, and the incorporation of top and side deteriorated silage in the TMR (Davies et al., 2018). The risk of incorporating deteriorated silage in dairy rations can be reduced by planning the size of a silo to achieve the correct daily feed-out rate and by properly packing, covering, and sealing the silo to minimize oxygen penetration during the conservation phase (Borreani et al., 2018). Thus, it is crucial to create strategies to identify aerobic deterioration in the early stages, before a silage becomes visibly molded. Moldy silage can easily be appraised through a visual inspection and then discarded, but unfortunately, there may be other parts of the silage face that are spoiled but which do not appear visually different from the stable and healthy part of the silage, thus leading to 
the risk of incorporating spoiled parts in the TMR. A field method already exists to detect corn silage spoilage; it relates the temperature in the central core of the silo (reference) to that measured in other locations of the silo face, such as in the peripheral areas close to the sealant film (within $0.4 \mathrm{~m}$ ), which are more prone to aerobic deterioration (Borreani and Tabacco, 2010). However, in some situations, when an excessive heat has accumulated in the core of the silage, as a result of forage respiration during silo filling (high environmental temperatures coupled with delayed silo filling), this technique can lead to problems of interpreting the results. The ideal situation would be to detect all the spoiled and spoiling silage and avoid including it in the feed ration. It is currently impossible to accurately and timely evaluate the microbial and chemical quality of the whole working face in a cost-efficient way or in a routine manner on a farm during the feed-out phase (Davies et al., 2018). Hence, simple methods that enable a forage producer to quickly and accurately assess the silage quality and the extent of aerobic deterioration at the silo face are essential. The first phase of aerobic deterioration is usually caused by yeasts, which start to utilize the residual sugars and lactic acid, and the first outcome is an increase in the temperature and in the $\mathrm{pH}$ (Pahlow et al., 2003), which can easily be measured on a farm (Bernardes et al., 2019).

Although many factors may affect silage losses during feed-out (e.g., silage density, fermentation profile, microbial counts, time of conservation), the feed-out rate is one of the factors that influences silage spoilage the most during aerobic deterioration in commercial horizontal silos (Mahanna and Chase, 2003; Borreani et al., 2018). The feed-out rate is generally measured as the mean linear progress of the unloading of a silo face as a result of the daily consumption of silage $(\mathrm{m} /$ wk). When this index is used to predict the risk of the aerobic spoilage of farm silages, different results emerge according to the silage densities or environmental temperatures (Holmes and Muck, 2007; Borreani et al., 2018). De Oliveira et al. (2018) proposed a new approach to integrate the linear feed-out rate (LFR) and density in one indicator that is easily measurable on a farm and which expresses the daily feed-out silage amount taken from a square meter of silo face. This method is fast and easy to use as it is able to reduces the difficulties involved in measuring silage densities and the mean daily or weekly LFR.

We hypothesized that feed-out rate recommendations may be more precise when the silage density is included in the model, thus the aims of this study were (1) to analyze silo management factors applied on commercial farms in 2 different environments (tropical and temperate countries); and (2) to develop an unloading rate index that considers silage density, based on daily silage consumption, related to the silo face size, to better predict the aerobic deterioration of silage and to obtain management solutions that could be used to prevent spoilage in corn silages.

\section{MATERIALS AND METHODS}

\section{Characterization of the Dairy Farms}

Fifty-three dairy farms in the South, Southeast, and Midwest of Brazil (latitudes from 17 to $24^{\circ} \mathrm{S}$ ) and 44 dairy farms in North Italy (latitudes from 44 to $45^{\circ} \mathrm{N}$ ) participated in this project. Italian farms were selected with the aid and suggestions of technicians of Breeder Associations of Piedmont and Lombardy regions on the basis of the farmers' willingness to participate in the survey and to be representative of corn silage management in intensive small- and large-scale dairy farms of the Po plain in Northwest Italy. The selection of farms for the South, Southeast, and Midwest of Brazil was made in conjunction with the Minas Gerais Milk Producers Association and independent consultants. Samplings were conducted from 2016 to 2018 and were distributed over all the seasons (summer, fall, winter, and spring). The annual average temperature for the surveyed areas in Brazil (mean value of $30 \mathrm{yr}$ ) was $21.4^{\circ} \mathrm{C}$, with minimum and maximum temperature of 17.7 and $26.7^{\circ} \mathrm{C}$, respectively (Climatempo ConsultingStormgeo Company). The temperatures in the surveyed area in Northern Italy (mean value of $40 \mathrm{yr}$ ) were an annual mean of $11.8^{\circ} \mathrm{C}$ (average minimum 6.4; maximum $17.9^{\circ} \mathrm{C}$ ), $6.5^{\circ} \mathrm{C}$ (average minimum 1.0 ; maximum $11.6^{\circ} \mathrm{C}$ ) for winter, and $20.5^{\circ} \mathrm{C}$ (average minimum 14.1; maximum $27.2^{\circ} \mathrm{C}$ ) for summer (data from Aeronautica Militare, Ministero della Difesa, Rome, Italy). One corn silage bunker, which had been open for at least $20 \mathrm{~d}$, was examined on each farm on the sampling day. A detailed questionnaire (with questions on the amount of corn silage consumed daily as measured on the TMR mixer, the number of lactating dairy cows, the daily milk production, the silage storage time, the application of silage additives, and other silo management practices) was presented to the farmers on each farm. Most of the visited Italian farms managed the removal of silage from the feed-out face using self-loading mixing wagons that were able to remove silage to a depth of 0.15 to $0.30 \mathrm{~m}$ and at a width of 1.0 to $1.5 \mathrm{~m}$. Most of the farms completely renewed the front face of their silos within 1 to $3 \mathrm{~d}$. The majority of farms in Brazil unloaded silage using rotating scrapers, whereas silage removal through frontload bucket tractors and manual methods was less diffused. None of the surveyed farms removed silage using block cutters or silage grabbers. 
The size of the silo (height, width, length, and height of the silo walls) was measured for each sampled corn silage to determine the silo face area $\left(\mathrm{m}^{2}\right)$ worked during unloading. The visibly spoiled area on the opened face of the silo was measured and expressed as the percentage of the visibly spoiled area on the total face area. The daily silage consumption and the size of the silo face were measured to calculate the mass feed-out rate (MFR; $\mathrm{kg}$ of silage removed daily/silo face surface), which was expressed in kilograms of silage/square meter of silo face per day. The LFR was determined by measuring the average weekly progression of the silo face, signing on the 2 silo walls the position of the silo face and then measuring and averaging the distances in meters which occurs in a given period of at least $7 \mathrm{~d}$. Samples were taken for chemical and microbial analyses using a manual silage corer (45 $\mathrm{mm}$ diameter) in both the central core (about $1 \mathrm{~kg}$ ) and in 3 locations in peripheral areas at distances from the silo walls of 0.20 , 0.80 , and $1.60 \mathrm{~m}$, respectively, at 0.20 to $0.30 \mathrm{~m}$ from the top, and at a depth of $200 \mathrm{~mm}$ from the working face. The temperatures were measured in all the sampling points, before coring, using a digital thermometer (Italian sampling: Testo 925, Hotek Technologies Inc.; Brazilian sampling: P700 model, Dostmann Electronic $\mathrm{GmbH}$ ) equipped with a 400-mm fast-action thermocouple probe ( $5 \mathrm{~mm}$ diameter) placed at the same locations to determine $\mathbf{d T}$; that is, the difference between the silage sample and the core silage temperatures, as recommended by Borreani and Tabacco (2010). The difference between the $\mathrm{pH}$ in the peripheral areas and the $\mathrm{pH}$ in the core, which was used as a reference, was defined as the $\mathrm{pH}$ index $(\mathbf{d p H})$. The samples were stored in plastic bags, kept at $2^{\circ} \mathrm{C}$ and transported to a laboratory. All the analyses took place within $10 \mathrm{~h}$ from sampling. The following variables were considered to identify silage spoilage: $\mathrm{dT} \geq 5^{\circ} \mathrm{C}$, that is, the difference between the temperature of the silage sample in the peripheral areas of the silo and the temperature in the core at a depth of $400 \mathrm{~mm}$ inside the silo face, as previously proposed by Borreani and Tabacco (2010); yeast count $>5 \log \mathrm{cfu} / \mathrm{g}$, as suggested by Pahlow et al. (2003), and mold count $>5 \log \mathrm{cfu} / \mathrm{g}$, set as a threshold for visibly molded silages (Borreani and Tabacco, 2010). The silage density was measured in 2 sections and at 4 different levels by coring a known volume according to D'Amours and Savoie (2005).

\section{Sample Preparation and Analyses}

The silage samples were split into 5 subsamples. One subsample was analyzed immediately for the DM content by oven drying at $80^{\circ} \mathrm{C}$ for $24 \mathrm{~h}$. Dry matter was corrected, according to Porter and Murray (2001), to consider the volatile compound losses that can take place at $80^{\circ} \mathrm{C}$. The second subsample was oven-dried at $65^{\circ} \mathrm{C}$ to a constant weight and was air-equilibrated for $48 \mathrm{~h}$, weighed, and ground in a mill (Cyclotec, Tecator) to pass a 1-mm screen. It was then analyzed for ash and total nitrogen $(\mathrm{CP}=$ total nitrogen $\times 6.25)$ by means of the Kjeldahl method, according to AOAC International (2005). The samples were treated with a heat stable $\alpha$ amylase, without sodium sulfite inclusion, to determine the NDF concentrations (filtered on a pre-tared coarse sintered glass crucible), and the results were corrected for residual ash (Van Soest et al., 1991). Samples were analyzed for the starch concentration according to AOAC method 920.40 (AOAC International, 2005).

The third subsample was used to obtain the microbial counts. Thirty grams of silage was transferred into sterile homogenization bags before being suspended in a peptone physiological salt solution $(270 \mathrm{~mL})$ and was then homogenizing for $4 \mathrm{~min}$ at $200 \mathrm{rpm}$ in a laboratory Stomacher blender (model 400 circulator; Seward Ltd.). Subsequently, 10-fold dilutions were prepared to quantify the microbial groups. Yeasts and molds were counted using the spread plate technique on YGC Agar (Fluka, Sigma Aldrich Química) after incubation at $25^{\circ} \mathrm{C}$ for 3 and $5 \mathrm{~d}$ for yeast and mold, respectively. The yeast and mold counts were performed separately, according to their macromorphological features, on plates that yielded 1 to $100 \mathrm{cfu}$.

For the fourth subsample, an aliquot of $30 \mathrm{~g}$ of silage was homogenized with $270 \mathrm{~mL}$ of deionized water and blended in a 400-mL bag, using a Stomacher blender (model 400 circulator) for $4 \mathrm{~min}$ at $200 \mathrm{rpm}$. The $\mathrm{pH}$ was then measured using an electrode (model Edge HI 11310; Hanna Instruments).

The fifth subsample was extracted, using a Stomacher blender (model 400 circulator), for $4 \mathrm{~min}$ in 0.05 $\mathrm{mol} / \mathrm{L} \mathrm{H}_{2} \mathrm{SO}_{4}$ at a $4: 1$ acid-to-sample material (fresh weight) ratio. An aliquot of $40 \mathrm{~mL}$ of silage acid extract was filtered with a $0.20-\mu \mathrm{m}$ syringe filter and used for quantification of the fermentation products. The lactic and monocarboxylic acids (acetic, propionic, and butyric acids) were determined, by means of HPLC, in the acid extract (Canale et al., 1984). Ethanol and 1,2-propanediol were determined by means of HPLC, coupled to a refractive index detector, on an Aminex HPX-87H column (Bio-Rad Laboratories).

\section{Statistical Analyses}

The microbial counts were log-transformed before analysis and presented as log values. The 3 samples obtained from the peripheral areas of the silages were averaged to perform statistical analyses. To assess how MFR affected silage spoilage, the silos were grouped 
into 4 classes, according to the criteria identified by Borreani et al. (2018) for LFR: <90, 90-150, >150-250, and $>250 \mathrm{~kg} / \mathrm{m}^{2}$ per day. The Satterthwaite approximation for the denominator degrees of freedom was applied to estimate denominator degrees of freedom. Data were analyzed using the MFR classes as fixed factors. The statistical model used was $Y_{i}=\mu+\alpha_{i}$ $+\varepsilon_{\mathrm{i}}$, where $Y_{\mathrm{i}}=$ observation, $\mu=$ overall mean, $\alpha_{\mathrm{i}}=$ MFR class, and $\varepsilon_{\mathrm{i}}=$ error. When $P$-values were $<0.05$, Tukey's post hoc test was used to interpret the differences between the classes. An unpaired $t$-test was used to compare the mean values of the $\mathrm{pH}$, lactic acid, yeast, and mold counts for each MFR class. All the MFR statistical analyses were conducted using the Statistical Package for Social Science (v 26.0, IBM Corp.). The Pearson correlations of the fermentative, chemical, and microbial analyses, $\mathrm{dpH}, \mathrm{dT}$, and MFR, were obtained using the Statistical Package for Social Science (v 26.0, IBM Corp.). The silages in peripheral areas of the silo were classified as not deteriorated or with signs of aerobic deterioration considering the following variables: yeast and mold counts, silage temperature, $\mathrm{pH}$, and lactic acid. The corn silage was attributed to the deteriorated silage class when at least 2 of the variables listed above exceeded the following thresholds: yeast count $>5 \log \mathrm{cfu} / \mathrm{g}$ (as suggested by Pahlow et al., 2003); mold count $>5 \log \mathrm{cfu} / \mathrm{g}$; silage temperature $>30^{\circ} \mathrm{C}$; lactic acid content $<10 \mathrm{~g} / \mathrm{kg} \mathrm{DM}$; and $\mathrm{pH}>4.5$ (Borreani and Tabacco, 2010). The need to use at least 2 variables is because in some conditions, temperature higher than $30^{\circ} \mathrm{C}$ can be attributable to respiration processes at ensiling coupled with high environmental temperatures. Furthermore, the silages were also attributed to the deteriorated silage class by considering using dT $>5^{\circ} \mathrm{C}, \mathrm{dpH}>0.25$ (Gervásio et al., 2018), and the yeast and mold counts $>5$ log cfu/g within each MFR class. When the yeast, mold, $\mathrm{dT}$, or $\mathrm{dpH}$ identified a sample as being negative, but at least 2 of the variables mentioned above were positive, the response was identified as a false negative. On the other hand, when the yeast, mold, dT, or dpH identified a sample as being positive, but that was the only positive variable, the response was identified as a false positive. The false positive and false negative frequencies were determined for each variable by comparing them with the abovementioned classification of deteriorated or nondeteriorated silages.

\section{RESULTS}

The number of lactating cows, individual and farm milk productions, silo size and characteristics, and silage consumption of the dairy farms surveyed in the 2 countries are reported in Table 1 . The survey included a wide range of milking cows, milk yields, and daily corn silage consumptions, ranging from 250 to 9,300 $\mathrm{kg} / \mathrm{d}$ and from 295 to $62,000 \mathrm{~kg} / \mathrm{d}$ for the Italian and Brazilian farms, respectively. The selected farms in both environments included those that performed well, moderately well, or poorly in terms of silage management, based on the criteria previously described by Bernardes and do Rêgo (2014) and Borreani et al. (2019). A large variability was observed for the silo size and silage density in the 2 countries. The variation in the daily consumption of corn silage for livestock influenced the LFR and the MFR, and large variations were observed, with mean values of 1.42 and $3.04 \mathrm{~m} /$ wk and 115 and $323 \mathrm{~kg} / \mathrm{m}^{2}$ per day, for Italy and Brazil, respectively. The DM content resulted to be lower in Brazilian than in Italian silages due to harvesting in earlier stages. The inoculants were applied in 11 out of 53 of the silages in Brazil and in 7 out of 44 of the farms in Italy. The Brazilian farms mainly used homolactic bacteria, whereas the Italian farms mainly used $L$. buchneri-based inocula (data not shown). The relationship between the LFR and MFR of the surveyed corn silages is reported in Figure 1. The 2 indexes indicated different relationships for the 2 groups of farms, with coefficients of determination of 0.937 and 0.776 for Brazil and Italy, respectively.

The main nutritional, fermentative, and microbial characteristics of silage sampled in the core, split into the 4 identified MFR classes, are listed in Table 2. No significant differences between MFR classes were observed for most of the characteristics, except for the ash and CP contents. The ash content decreased slightly as the MFR classes increased, whereas the CP content increased slightly as the MFR increased. The DM content and $\mathrm{pH}$ ranged between 22.1 and $43.9 \%$, and between 3.45 and 4.15 , respectively. The lactic and acetic acids showed average values of 4.97 and $2.19 \%$ DM, respectively. The butyric acid was below or very close to the detection limit in almost all the core silages in the different MFR classes. The yeast and mold counts ranged from values below the detection limits to values of 6.07 to $3.08 \log \mathrm{cfu} / \mathrm{g}$, respectively.

The main nutritional, fermentative and microbial characteristics of the silage sampled in the peripheral areas of the operating silo faces, during the feed-out phase, are listed in Table 3. Several characteristics showed significant differences between the MFR classes, thus indicating a strong influence of MFR on silage quality in the peripheral areas of the silo. The CP, NDF, lactic acid, and ethanol concentrations increased as the MFR class increased, whereas the starch, dT, and the yeast and mold counts decreased with increasing MFR. An average butyric acid content of $0.12 \%$ DM was observed in the silages with MFR values below $150 \mathrm{~kg} / \mathrm{m}^{2}$ per day, whereas the average value drops to $0.01 \% \mathrm{DM}$ 
for the silages with higher MFR values than $250 \mathrm{~kg} / \mathrm{m}^{2}$ per day. The $\mathrm{dT}$ and $\mathrm{dpH}$ showed values that ranged from close to zero (no aerobic deterioration) to highly positive, thus indicating an ongoing aerobic deterioration process in the peripheral areas of the silo. The $\mathrm{pH}$, lactic acid, yeast, and mold counts of the core and peripheral silages, as affected by MFR, are reported in Figure 2. The higher the MFR class is, the lower the differences in the $\mathrm{pH}$, lactic acid, and the yeast and mold counts between the 2 silo zones. Silos with a higher MFR than $250 \mathrm{~kg} / \mathrm{m}^{2}$ per day did not show any significant differences between the core and peripheral areas for $\mathrm{pH}$, lactic acid content, or molds.

The frequencies of the total data set and the 4 identified MFR classes pertaining to the nonaerobic deteriorated silages, silages with yeast below $5 \mathrm{log} \mathrm{cfu} / \mathrm{g}$, silages with mold below $5 \mathrm{log} \mathrm{cfu} / \mathrm{g}$; silages with $\mathrm{dpH}$ below 0.25 , and silages with $\mathrm{dT}<5^{\circ} \mathrm{C}$, are reported in Table 4 . The silages with no sign of aerobic deterioration account for $61.9 \%$ of the total surveyed farms, and the presence of signs of aerobic deterioration decreased as the MFR increased. The $>250 \mathrm{~kg} / \mathrm{m}^{2}$ per day MFR class included $92.5 \%$ of the silage without aerobic deterioration. The $\mathrm{dpH}$ and $\mathrm{dT}$ indexes used to identify aerobic deterioration were tested to establish their capacity to correctly identify aerobic deteriorated or not deteriorated silages. Overall, a dpH value of below 0.25 and a $\mathrm{dT}>5^{\circ} \mathrm{C}$ correctly identify the silage status in $86.6 \%$ and $93.8 \%$ of the total cases, respectively. The $\mathrm{dpH}$ presented frequencies that were closely related to the frequencies of the nondeteriorated silages (3 out of 60 false positives), but high frequencies of the false negatives (11 out of 37 ); $\mathrm{dT}<5^{\circ} \mathrm{C}$ showed a higher ability to identify the presence of aerobic deterioration than $\mathrm{dpH}$, with 5 out of 60 false positives and 3 out of 37 false negatives. Yeast and mold counts above 5 $\log \mathrm{cfu} / \mathrm{g}$ were able to correctly identify aerobic deterioration in 86.6 and $75.3 \%$ of all the studied silos, respectively.

The Pearson correlation coefficients of the different measured characteristics are reported in Tables 5 and 6 for the core and peripheral areas, respectively. The core silages showed a significant correlation between the storage time, yeast count, and lactic acid content and between the DM content and propionic acid, NDF, $\mathrm{CP}$, and starch contents. The acetic acid content was negatively correlated with the yeast count and negatively correlated with contents of 1,2-propanediol and ethanol. The peripheral silages showed several significant correlations between most of the measured characteristics. The higher the MFR is, the lower the yeast, mold, $\mathrm{dpH}, \mathrm{dT}, \mathrm{pH}$, and ash content, and the higher the lactic and acetic acid and ethanol contents.

\section{DISCUSSION}

The main aim of the present study was to understand the role of the removal rate on the aerobic deterioration of corn silages in 2 different environments. The main factors that influence the aerobic deterioration of silages conserved in horizontal silos are the correct removal rate from the silo, the silage density, the covering and the weighing down of shoulder and top sheets, the use of additives, and the ambient temperature (Borreani et al., 2018).

However, uncontrollable climate-related factors can also influence the final quality of a silage. High temperatures can increase the risk of butyric fermentation and aerobic deterioration of silages and can negatively affect the yield and nutritive value of corn (Bernardes

Table 1. Silo size, storage time, density, and daily consumption of corn silages from Brazilian $(\mathrm{n}=53)$ and Italian $(\mathrm{n}=44)$ farms

\begin{tabular}{|c|c|c|c|c|c|c|c|c|}
\hline \multirow[b]{2}{*}{ Item $^{1}$} & \multicolumn{4}{|c|}{ Italy } & \multicolumn{4}{|c|}{ Brazil } \\
\hline & Mean & SEM & Minimum & Maximum & Mean & $\mathrm{SE}$ & Minimum & Maximum \\
\hline Number of lactating cows & 115 & 12 & 6 & 300 & 206 & 40 & 12 & 1,800 \\
\hline Daily milk production (L/farm) & 3,276 & 368 & 130 & 9,690 & 5,884 & 1,478 & 100 & 68,000 \\
\hline Mean production (L/cow per day) & 26.8 & 0.6 & 11.5 & 33.2 & 21.6 & 1.2 & 4.8 & 37.9 \\
\hline Silo length $(\mathrm{m})$ & - & & - & - & 42 & 2.8 & 14 & 100 \\
\hline Silo width (m) & 9.0 & 0.5 & 3.4 & 15.7 & 7.3 & 0.9 & 2.4 & 43.0 \\
\hline Silo wall height (m) & 2.5 & 0.1 & 1.5 & 3.5 & 2.4 & 0.1 & 1.0 & 5.0 \\
\hline Silage height $(\mathrm{m})$ & 2.4 & 0.1 & 1.8 & 3.9 & 2.8 & 0.1 & 1.4 & 5.5 \\
\hline Silo face area $\left(\mathrm{m}^{2}\right)$ & 28 & 2.0 & 7 & 61 & 23 & 4.2 & 3 & 169 \\
\hline Silage storage time (d) & 139 & 15 & 22 & 392 & 143 & 15.5 & 30 & 600 \\
\hline Silage density $\left(\mathrm{kg} / \mathrm{m}^{3}\right)$ & 594 & 10 & 388 & 697 & 735 & 19.5 & 421 & 1,006 \\
\hline Silage DM content (\%) & 35.6 & 0.50 & 30.2 & 43.3 & 32.9 & 0.59 & 22.2 & 43.9 \\
\hline Silage density (kg of $\left.\mathrm{DM} / \mathrm{m}^{3}\right)$ & 211 & 4.1 & 143 & 268 & 242 & 7.0 & 109 & 328 \\
\hline Silage consumption $(\mathrm{kg} / \mathrm{d})$ & 3,279 & 342 & 250 & 9,300 & 7,301 & 1,411 & 295 & 62,000 \\
\hline LFR (m/wk) & 1.42 & 0.15 & 0.35 & 4.60 & 3.04 & 0.33 & 0.69 & 12.82 \\
\hline $\operatorname{MFR}\left(\mathrm{kg} / \mathrm{m}^{2}\right.$ per day $)$ & 115 & 10.5 & 28 & 280 & 323 & 36.7 & 72 & 1,400 \\
\hline
\end{tabular}

${ }^{1} \mathrm{LFR}=$ linear feed-out rate; $\mathrm{MFR}=$ mass feed-out rate. 


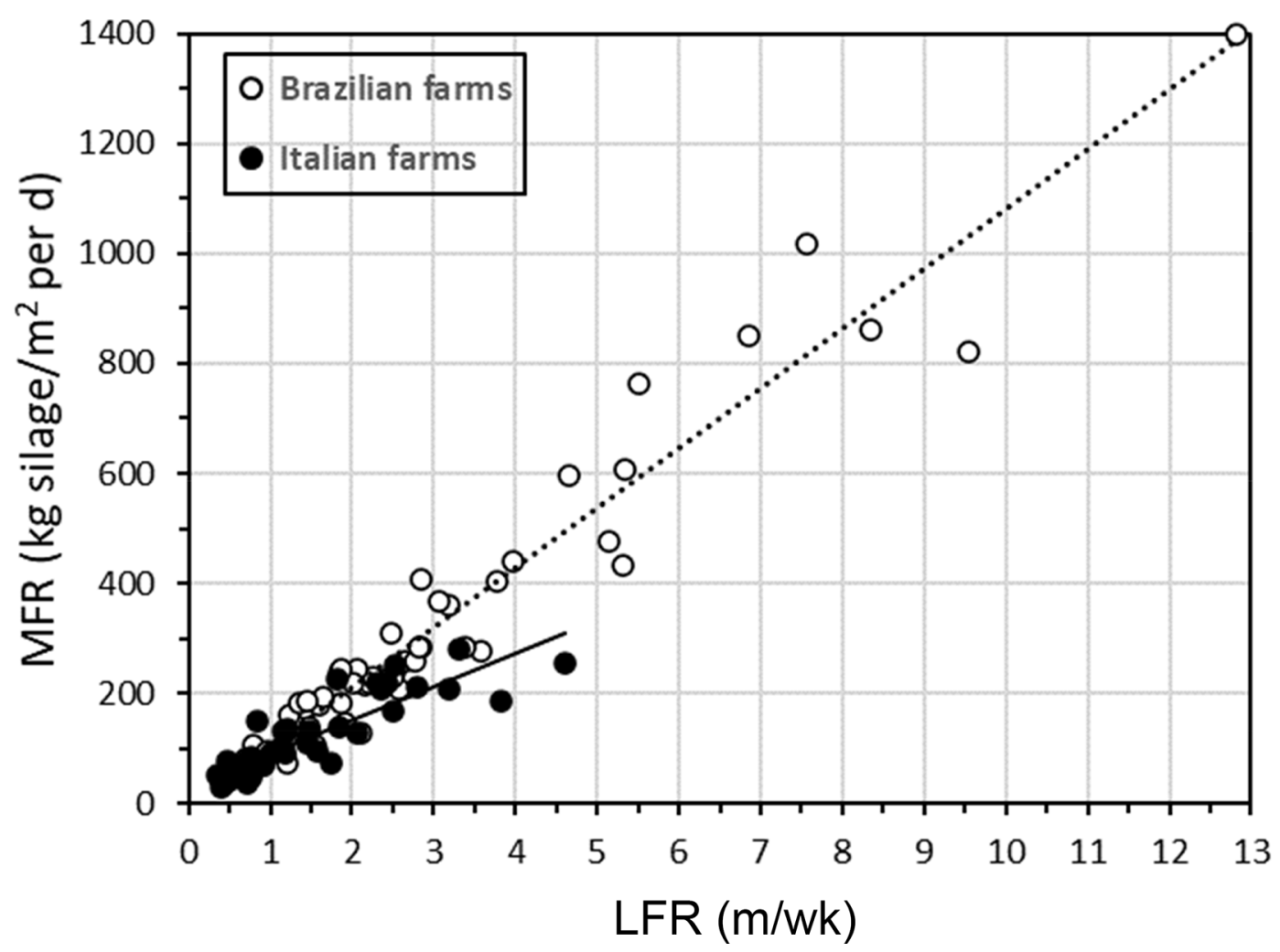

Figure 1. Relationship between linear feed-out rate (LFR) and mass feed-out rate (MFR) of the corn silages in the studied dairy farms of 2 countries. Dotted line: linear regression for Brazil, MFR $=108.9 \times \mathrm{LFR}-8.43 ; \mathrm{R}^{2}=0.937 ; P<0.001$; root mean square error $(\mathrm{RMSE})=68.7$; $\mathrm{n}=53$. Continuous line: linear regression for Italy, MFR $=60.9 \times \mathrm{LFR}+28.5 ; \mathrm{R}^{2}=0.776 ; P<0.001 ; \mathrm{RMSE}=33.5 ; \mathrm{n}=44$.

Table 2. Mean values (ranges in parentheses) of the chemical composition, fermentation end products, $\mathrm{pH}$, and microbial counts of the silages located at the core of the working face of the silo according to 4 mass feed-out rate classes (MFR)

\section{$\operatorname{MFR}\left(\mathrm{kg} / \mathrm{m}^{2}\right.$ per day)}

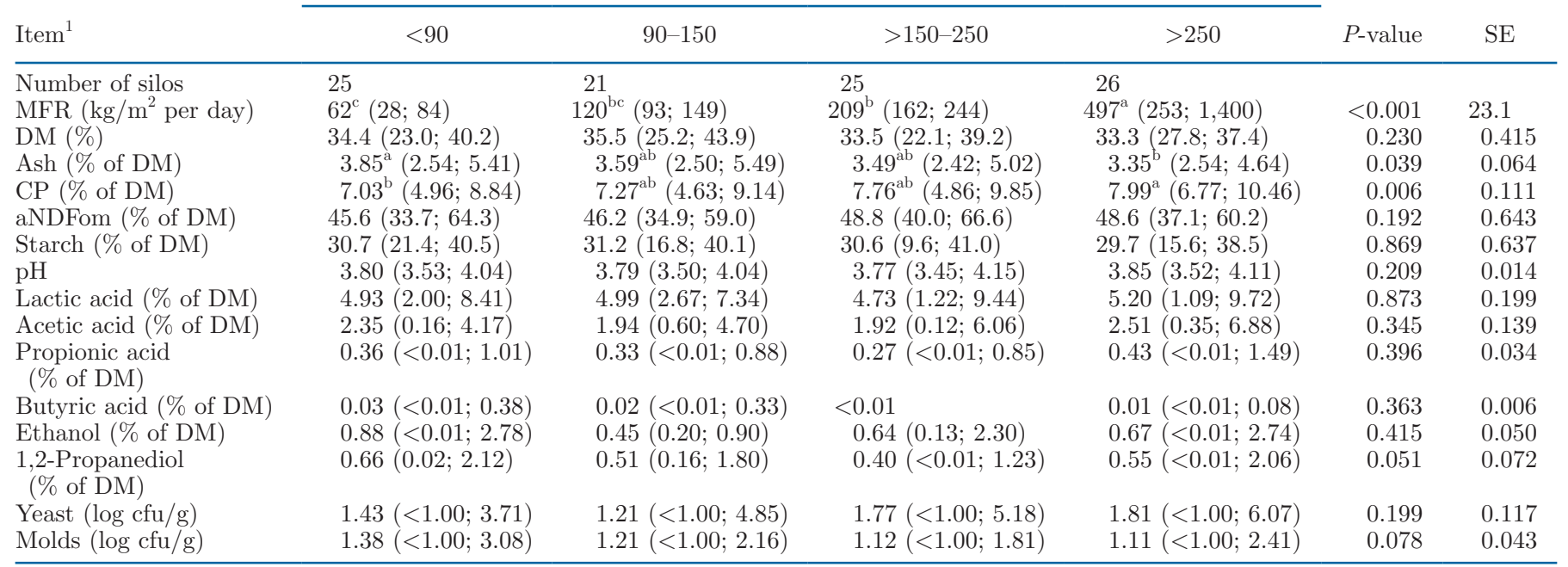

\footnotetext{
${ }^{a-c}$ Means within a row with different superscripts differ $(P<0.05)$ for Tukey post hoc test.

${ }^{1}$ aNDFom $=$ ash-free neutral detergent fiber.
} 
et al., 2018). The use of correct silage management practices (silage conservation in a bunker with concrete walls, fast silo filling during harvesting, the use of at least 2 plastic films to cover the silo top, the use of plastic film on the silo walls, and a correct feed-out rate) reduces the incidence of aerobic deterioration, as reported by Borreani et al. (2019) in a survey of 49 Italian dairy farms. Higher densities were observed on the Brazilian farms than on the Italian ones, mainly because of the higher mean silage height $(2.8 \mathrm{~m}$ vs. $2.4 \mathrm{~m}$ ) and lower mean DM content (32.9\% vs. $35.6 \%$ ) of the Brazilian silages. These higher densities coupled with lower DM contents of Brazilian silages led to less incidence of aerobic deterioration in Brazilian than Italian silages. The regression equations between LFR and MFR presented different slopes for the 2 groups of farms, because of the different harvesting machinery that was used, different silage compaction strategies, and different DM contents at harvesting, which led to different silage densities, which in turn affected the linear progress of the opened front face of the silo. Ensiling expertise, economic factors, and mechanization play a key role in obtaining high-quality silages (Bernardes et al., 2018). Many farms in Brazil harvest corn with their own equipment, which is often made up of a trailed forage harvester (Santos et al., 2020). This type of harvesting can result in a slow silo filling, which can last several days. In the forage mass that remains in contact with air, aerobic microorganisms consume soluble carbohydrates, thus leading to an increase in silage temperature and the risk of butyric fermentation rather than lactic fermentation (Borreani et al., 2018). Such a slow silo filling, coupled with the low weighting of the silo surface, can partially explain the higher yeast count and the presence of butyric acid in the core silage of some of the Brazilian farms ( 5 core silages with an average value of $0.21 \% \mathrm{DM}$ ) considered in the present study. Conversely, most Italian farms entrust silo filling and harvesting to contractors with high-performing self-propelled forage harvesters, and this leads to a very low frequency of butyric acid fermentation in the core of silages. Acetic acid, 1,2-propanediol, and propionic acid concentrations showed a large variation, thus indicating different fermentative profiles (from homofermentative to heterofermentative), as also confirmed by the lactate-to-acetate ratios (data not shown). The lactate-to-acetate ratio showed a mean value of 3.65 in the core samples, and ranged from 0.58 to 15.25 , thus indicating the presence of pure homolactic-to-marked heterolactic fermentation in the silages. In the present survey, butyric acid was only found in the core mass of 1 Italian farm, but at a concentration very close to the detection limit (data not shown). Conversely, 10 out of 53 and 14 out of 44 of the peripheral silage samples showed signs of the presence of butyric acid in Brazil and Italy, respectively. This may be attributable to the stimulation of clostridia growth as a result of aerobic microbial activity (increased temperature and $\mathrm{pH}$, as

Table 3. Mean values (ranges in parentheses) of the chemical composition, fermentation end products, $\mathrm{pH}$, microbial counts, dpH, and dT of the silages located at the peripheral areas of the working face of bunker silo according to 4 mass feed-out rate classes (MFR)

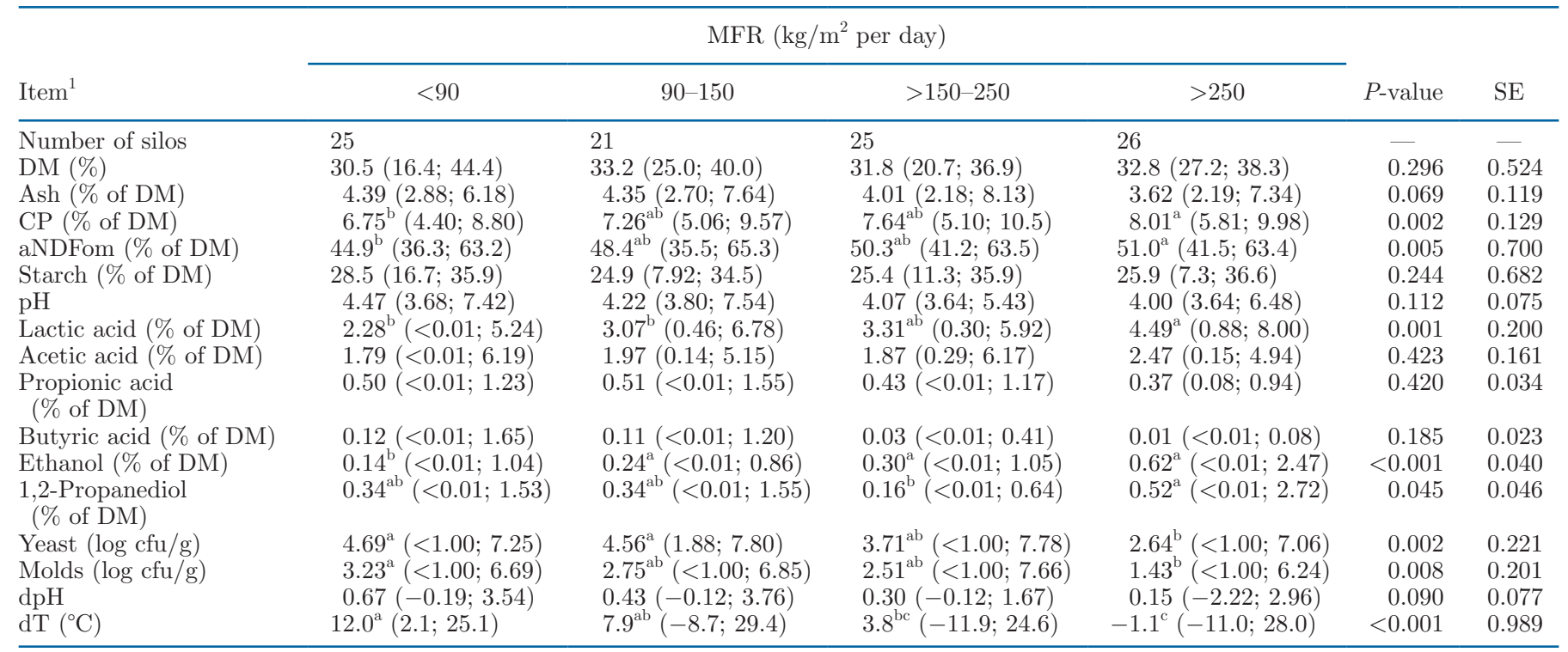

\footnotetext{
${ }^{\mathrm{a}-\mathrm{c}}$ Means within a row with different superscripts differ $(P<0.05)$ for Tukey post hoc test.

${ }^{1} \mathrm{dpH}=$ difference between the $\mathrm{pH}$ sample and the reference $\mathrm{pH}$ collected of the core of the silage at $200 \mathrm{~mm}$ behind the silage working face; $\mathrm{dT}$ $=$ difference between silage temperature and reference temperature of the core of the silage measured at $400 \mathrm{~mm}$ behind the silage working face; aNDFom $=$ ash-free neutral detergent fiber.
} 
well as restored anaerobic conditions as a result of oxygen depletion) during aerobic deterioration, as reported by Vissers at al. (2007).

The incidence of aerobic deterioration in the peripheral areas of the silos was greater on the Italian farms than on the Brazilian farms. This can be attributable to the lower silage density and the lower feed-out rates in Italy. Furthermore, the silo face area, in relation to the daily removed silage, was higher on the Italian farms than on the Brazilian farms, thus suggesting that the silos in Italy were oversized relative to the herd size and to silage consumption on several farms.

In the present study, the core silages presented a great variability in nutritional quality between farms and countries. This variability is mainly attributable to the stage of the corn in the field at harvesting and the climatic conditions (Opsi et al., 2013; Bernardes et al., 2018). Positive correlations between the DM content and starch content, and negative correlations between the DM content, $\mathrm{NDF}$, and $\mathrm{CP}$ contents were observed in the core mass of the silages. These correlations can be explained by considering the effect of corn silage harvested at different stages of maturity, as reported in several studies (Allen et al., 2003; Opsi et al., 2013). The higher the DM content is at ensiling, the lower the NDF and the higher the starch content of the whole corn crop (Johnson et al., 1999; Opsi et al., 2013). Harvesting at early stages of maturity can be unfavorable for a low DM content $(<30 \% \mathrm{DM})$ at ensiling and can influence the effluent losses of nutrients (Pahlow et al.,
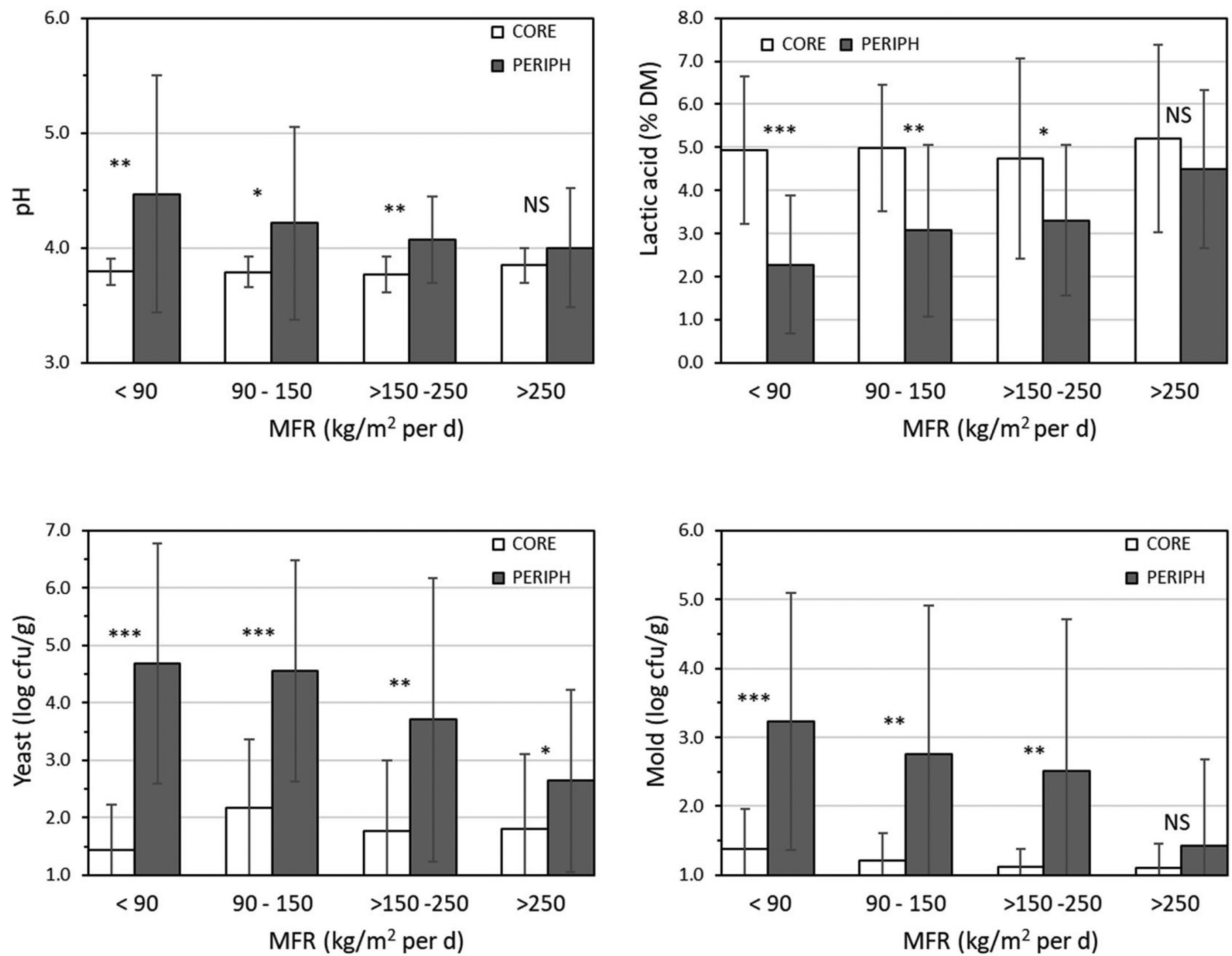

Figure 2. $\mathrm{pH}$, lactic acid, yeast, and mold counts of core and peripheral (PERIPH) silages as affected by mass feed-out rate (MFR). The significance was reported for each MFR class using the unpaired $t$-test; ${ }^{* * *} P<0.001 ;{ }^{* *} P<0.01 ;{ }^{*} P<0.05$; NS: $P>0.05$. Error bars represent SD. 
2003). Furthermore, the net energy for lactation of the silage is lower than at a late stage of maturity, due to an incomplete starch accumulation in the kernels. Conversely, delaying the harvest to close to the black layer stage results in a greater DM content than $40 \%$ and reduced starch and fiber digestibility, with a consequent reduction in the milk yield performances (Allen et al., 2003; Ferraretto and Shaver, 2012). Furthermore, a higher DM content than $40 \%$ leads to greater difficulties in packing, and it may accelerate silage deterioration when it is exposed to air (Comino et al., 2014).

Recent advances in the microbial ecology of corn silages during aerobic deterioration have clarified the aerobic deterioration process, the succession of microbial populations, and the evolution of nutritional and hygienic qualities (Ferrero et al., 2019; Drouin et al., 2021). To feed high-quality silages, it is important to identify the conservation status of the silage, especially in the peripheral areas of a silo, where it is more difficult to achieve a high silage density and to totally exclude oxygen permeation into the mass (Borreani et al., 2018). When a corn silage is exposed to air, it remains stable for a few hours to several days (aerobic stability), the aerobic deterioration process then begins, and 3 different stages can be identified. The first stage, which is commonly acted by yeasts or acetic acid bacteria (Pahlow et al., 2003), involves a fast depletion of the fermentative products (especially lactic acid and ethanol), and the residual soluble carbohydrates lead to a fast increase in temperature. This stage is easily identified at a farm level from the presence of high temperatures $\left(>30^{\circ} \mathrm{C}\right.$ or $\mathrm{dT}$ above $\left.5^{\circ} \mathrm{C}\right)$ coupled with a high yeast count (greater than $5 \log \mathrm{cfu} / \mathrm{g}$ ), whereas a reduced effect on silage $\mathrm{pH}$ is usually observed until most of the lactic acid has been consumed (Borreani and Tabacco, 2010; Ferrero et al., 2019). This stage is followed, within a few days, by a second stage, which is acted by yeasts and aerobic bacteria, whereby the temperature declines slightly, the fermentative products are exhausted completely, and the $\mathrm{pH}$ and ash content start to increase (Borreani et al., 2013; Drouin et al., 2021). This phase is easily identified at a farm level from the medium to high temperatures, yeast counts greater than $5 \mathrm{log} \mathrm{cfu} / \mathrm{g}$ and $\mathrm{pH}$ values above 4.5 in corn silages (Borreani and Tabacco, 2010; Ferrero et al., 2019), and dpH therefore becomes useful from this stage onward. In the third and last stage of aerobic deterioration, silage becomes visibly molded and assumes a slimy aspect. This stage is mainly activated by filamentous fungi and Bacillales; the temperature decreases and almost reaches that of the surrounding environment, the $\mathrm{pH}$ usually exceeds 6 , and a marked

Table 4. Average frequencies of yeast, $\mathrm{dpH}$, and $\mathrm{dT}$ below a defined threshold in the silages located at the top of bunker silo according to the mass feed-out rate (MFR)

\begin{tabular}{|c|c|c|c|c|c|}
\hline \multirow[b]{2}{*}{ Item $^{1}$} & \multirow[b]{2}{*}{ Total } & \multicolumn{4}{|c|}{$\operatorname{MFR}\left(\mathrm{kg} / \mathrm{m}^{2}\right.$ per day $)$} \\
\hline & & $<90$ & $90-150$ & $>150-250$ & $>250$ \\
\hline Number of silos (n) & 97 & 25 & 21 & 25 & 26 \\
\hline Not deteriorated (n) & 60 & 7 & 13 & 16 & 24 \\
\hline Deteriorated (n) & 37 & 18 & 8 & 9 & 2 \\
\hline Not deteriorated & 0.619 & 0.280 & 0.619 & 0.640 & 0.923 \\
\hline \multicolumn{6}{|l|}{ Yeast (log cfu/g) } \\
\hline$<5.00$ & 0.649 & 0.440 & 0.667 & 0.600 & 0.885 \\
\hline False positives & $5 / 60$ & $1 / 7$ & $0 / 13$ & $3 / 16$ & $1 / 24$ \\
\hline False negatives & $8 / 37$ & $5 / 18$ & $1 / 8$ & $2 / 9$ & $0 / 2$ \\
\hline Correctly identified & 0.866 & 0.760 & 0.952 & 0.800 & 0.961 \\
\hline \multicolumn{6}{|l|}{ Mold (log cfu/g) } \\
\hline$<5.00$ & 0.845 & 0.840 & 0.762 & 0.800 & 0.961 \\
\hline False positives & $1 / 60$ & $0 / 7$ & $1 / 13$ & $0 / 16$ & $0 / 24$ \\
\hline False negatives & $23 / 37$ & $14 / 18$ & $4 / 8$ & $4 / 9$ & $1 / 2$ \\
\hline Correctly identified & 0.753 & 0.440 & 0.762 & 0.840 & 0.961 \\
\hline$<0.25$ & 0.701 & 0.480 & 0.714 & 0.640 & 0.962 \\
\hline False positives & $3 / 60$ & $1 / 7$ & $0 / 13$ & $2 / 16$ & $0 / 24$ \\
\hline False negatives & $11 / 37$ & $6 / 18$ & $2 / 8$ & $2 / 9$ & $1 / 2$ \\
\hline \multirow{2}{*}{\multicolumn{6}{|c|}{$\mathrm{dT}\left({ }^{\circ} \mathrm{C}\right)$}} \\
\hline & & & & & \\
\hline$<5.00$ & 0.598 & 0.240 & 0.524 & 0.680 & 0.923 \\
\hline False positives & $5 / 60$ & $2 / 7$ & $3 / 13$ & $0 / 16$ & $0 / 24$ \\
\hline False negatives & $3 / 37$ & $1 / 18$ & $1 / 8$ & $1 / 9$ & $0 / 2$ \\
\hline Correctly identified & 0.938 & 0.880 & 0.810 & 0.960 & 1.00 \\
\hline
\end{tabular}

${ }^{1} \mathrm{dpH}=$ difference between the $\mathrm{pH}$ sample and the reference $\mathrm{pH}$ collected of the core of the silage at $200 \mathrm{~mm}$ behind the silage working face; $\mathrm{dT}=$ difference between silage temperature and reference temperature of the core of the silage measured at $400 \mathrm{~mm}$ behind the silage working face. 


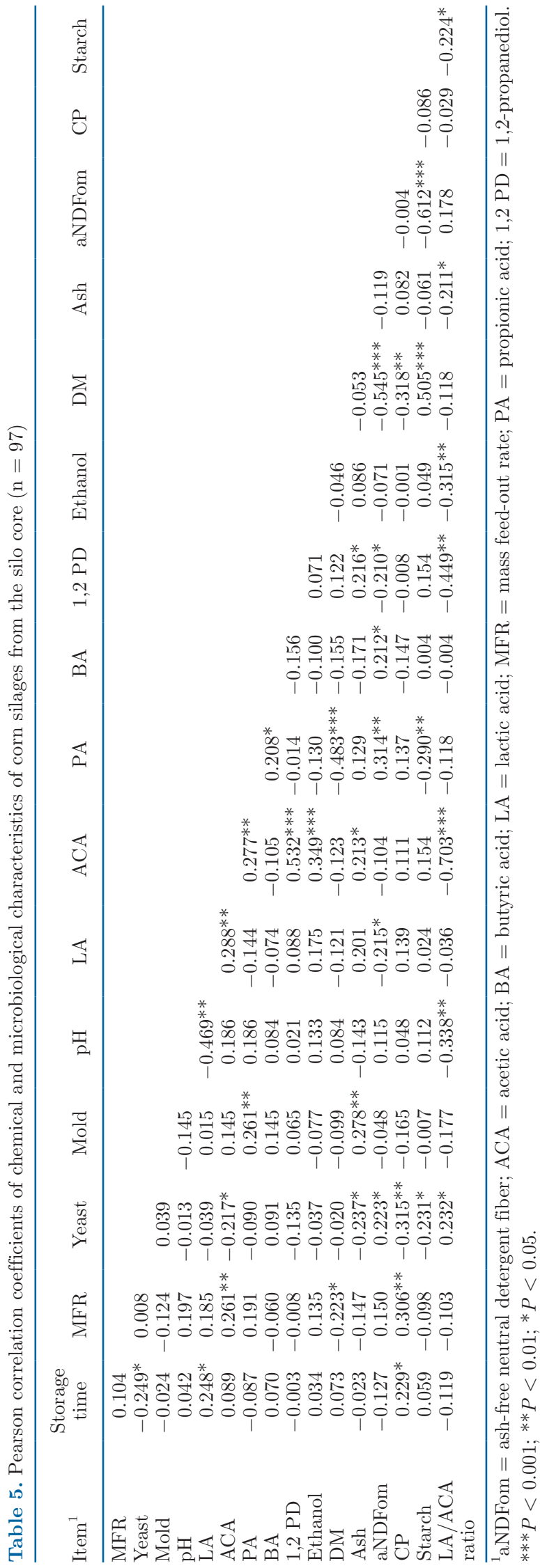

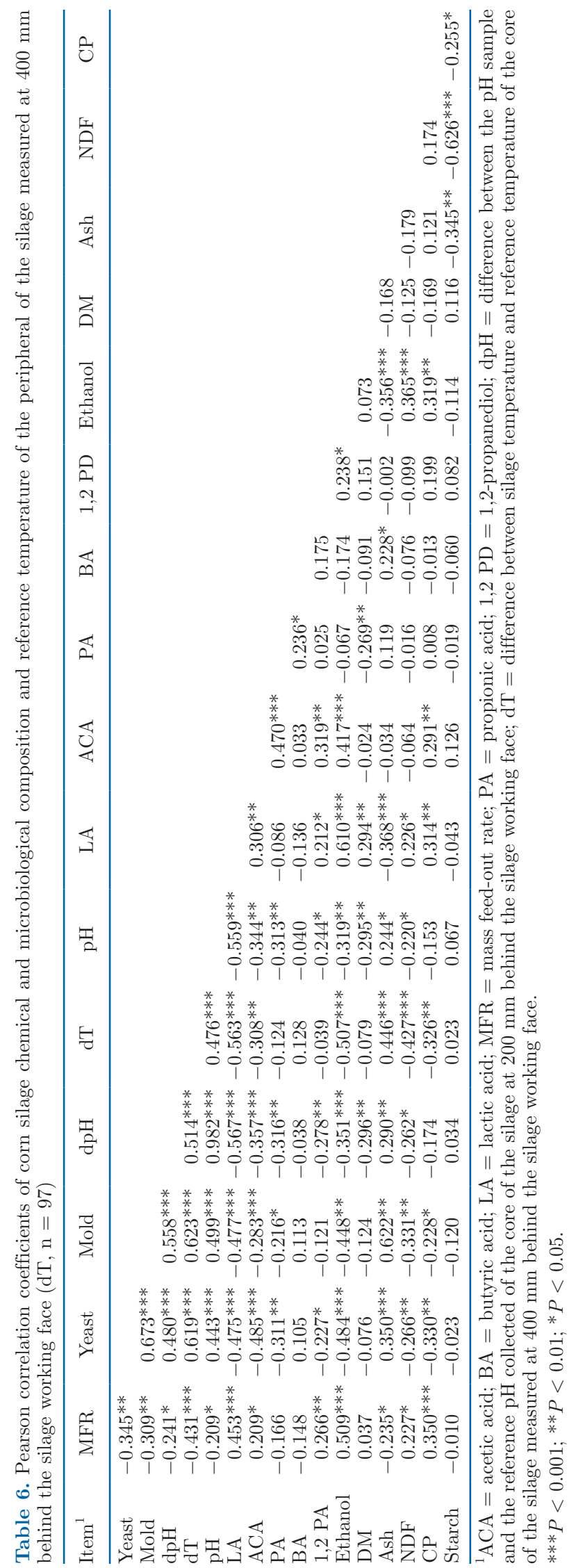


depletion of starch, together with an increase in NDF and the ash content, is frequently observed (Ferrero at al., 2019). The mold growth is commonly associated with an accumulation of toxic metabolites, such as mycotoxins (Ferrero et al., 2019; Drouin et al., 2021). Furthermore, during aerobic deterioration due to aerobic activity, the aerobic/anaerobic zone moves toward the surface of a silage exposed to air, anaerobiosis is restored in the deeper parts and anaerobic sporeformers (Clostridium spp.) can grow and multiply in this ecosystem in micro-niches with less inhibitory activity (Vissers et al., 2007; Borreani et al., 2019).

In the present paper, a marked effect of MFR on silage quality was evident when analyzing the microbial and fermentative qualities in the peripheral areas of the silos, associated with a decrease in $\mathrm{pH}, \mathrm{dpH}, \mathrm{dT}$, and in the yeast and mold counts, whereas an increase in lactic acid and in the ethanol contents was observed for increasing MFR classes. The Pearson correlation coefficients presented several significant values for the fermentative characteristics, MFR, dT, and $\mathrm{dpH}$, thus indicating that the aerobic microbial activity consumed fermentative products (lactic acid, acetic acid, and ethanol), as stated in Borreani and Tabacco (2010). Furthermore, a reduction in the differences between the peripheral areas and the core of the silage was observed from a comparison of the $\mathrm{pH}$, lactic acid, and the yeast and mold counts, as the MFR class increased, and this reduction resulted in nonsignificant differences for MFR greater than $250 \mathrm{~kg} / \mathrm{m}^{2}$ per day. It appears that the extent of aerobic deteriorated silage decreases as the MFR increases, and this leads to a more uniform quality of silage being taken from the feed-out silo face. This has confirmed the relevance of the feed-out rate during silage consumption and, therefore, the correct size of the silo in relation to the amount of silage consumed daily and the season in which the silage is used (Borreani et al., 2018).

A further objective of the current research was to develop and test tools that can be used to identify the aerobically deteriorated parts of silage on a farm quickly and easily. The fast identification of the aerobic deterioration process under way in commercial silos is a long-time goal for farmers and nutritionists, to avoid risks connected to feeding aerobic deteriorated silages to animals (Ruppel et al., 1995). Borreani and Tabacco (2010) proposed the dT index, which is calculated as the difference between the temperature measured in the core of the silo and the temperature of the sample. They stated that when the $\mathrm{dT}$ is greater than $5^{\circ} \mathrm{C}$, there is a high probability that there is an ongoing aerobic deterioration process. The method works well at the beginning of aerobic deterioration, as activated by yeast activity, and when the core temperatures in the silage are not too high. The method does not work in visibly advanced moldy silages, where the microbial activity has slowed down and the heat release through respiration is less evident (Borreani and Tabacco, 2010). Therefore, dT should be coupled with the identification of visible molded spots that should be considered deteriorated in any case. Other variables may be useful to identify aerobically deteriorated silages, such as the yeast and mold count, $\mathrm{pH}$, the ash content, and the fermentative characteristics, although obtaining most of them is time consuming and expensive and they are not able to give fast results on a farm (Borreani et al., 2018). In the present study, dpH and $\mathrm{dT}$ were tested as a single indicator to identify aerobically deteriorated areas of the silo face, together with yeast and mold counts. Both $\mathrm{dpH}$ and $\mathrm{dT}$ correctly identified the aerobic deterioration in $86.6 \%$ and $93.8 \%$ of the studied silos, respectively.

A greater number of false negative samples was detected when $\mathrm{dpH}$ was used as the only indicator. A possible explanation for this source of error could be attributable to the beginning of the aerobic deterioration phase, when the rapid yeast growth determines a fast increase in temperature, whereas $\mathrm{pH}$ does not increase until most of the lactic acid has been consumed (i.e., $\mathrm{pH}$ begins to increase significantly when lactic acid is below $15 \mathrm{~g} / \mathrm{kg}$ of DM; Borreani and Tabacco, 2010). However, dT produced erroneous indications of aerobic deterioration in $6.3 \%$ of the cases, mainly false negatives, which were attributable to the advanced stage of aerobic deterioration, with the presence of visible mold and a decrease in the silage temperature in the peripheral areas, or to a high temperature in the core of the silage, due to a delay in sealing the silo, which masked high peripheral temperatures.

Borreani and Tabacco (2012) underlined the importance of coupling high linear feed-out rates with careful silo management to reduce the risk of aerobic deterioration. They recommended minimum weekly unloading rates from horizontal silos during feed-out to prevent aerobic deterioration in different countries, in relation to the environmental temperature and season (Borreani et al., 2018). The measurement of a correct linear feedout rate is not always easy and could be influenced by different DM densities of the silos (De Oliveira et al., 2018). Therefore, De Oliveira et al. (2018) proposed a MFR (expressed in kilograms of silage per square meter per day) that only requires easily measured variables, such as the area of the working silo face and the amount of fresh silage taken daily from the silo. Furthermore, to correctly measure the LFR, at least 2 farm visits are needed to record the progress in the feed-out face (with an interval of at least $1 \mathrm{wk}$ ), whereas only 1 visit is needed for the MFR index. The LFR and MFR indexes 
are correlated, but differences exist between the Italian and Brazilian farms due to the different silo management procedures and DM contents at ensiling, which lead to different silage densities. Therefore, the suggestion of a minimal LFR to prevent aerobic deterioration from 1.5 to $2.1 \mathrm{~m} / \mathrm{wk}$ for temperate and warmer environments, as reported in literature (Borreani et al., 2018), corresponds to a mean daily MFR ranging from 155 (75 to 181$)$ to 220 (128 to 244$) \mathrm{kg} / \mathrm{m}^{2}$, which are close to the optimum $\left(250 \mathrm{~kg} / \mathrm{m}^{2}\right)$ and critical $(150 \mathrm{~kg} /$ $\mathrm{m}^{2}$ ) values of MFR obtained in the current study. Our data set, which is characterized by a wide range of management conditions, indicates that the MFR could be more precise than LFR, because it includes the effect of density, as previously suggested by Holmes and Muck (2007). These authors suggested that the minimum LFR recommended to maintain DM losses below 3\%, should be $0.4,0.7$, and $1.4 \mathrm{~m} / \mathrm{wk}$ for silage densities of 961, 641, and $481 \mathrm{~kg} / \mathrm{m}^{3}$, respectively. This confirms that the silage density plays a key role in preventing the onset of aerobic deterioration and should be taken into account when suggesting recommended feed-out rates, especially when different silage management practices are applied on farms. An advantage of using MFR, in recommending silage removal rate, is its ability to consider different feed-out methods (defacers, block cutters, rotating scrapers) and management procedures (width and depth of silage unloading), which can affect the time necessary to complete the silo face and ultimately the amount of spoiled silage fed to animals.

Further works are needed to coupling silo management and season to give more detailed indication about interaction between MFR, season, and silage management. In the present paper we analyzed this aspect in general because to many factors interact in the present survey to be able to clearly identify seasonal interaction with MFR.

\section{CONCLUSIONS}

Planning the size of a silo, considering the total amount of silage removed daily, may ensure a correct feed-out rate. The new MFR index has proved to be able to substitute for the widely used LFR, because it includes the effect of silage density and can be obtained from a single recording. It was evident that the microbial and fermentative qualities of the silage sampled in the core were mainly unaffected by the MFR. Instead, the higher the MFR was, the lower the differences in the microbial and nutritional quality between the peripheral areas of the silo face and the core of the silage, thus resulting in a more uniform high-quality silage over the whole profile of the silo for the entire year. A daily removal rate of over $250 \mathrm{~kg}$ of silage $/ \mathrm{m}^{2}$ markedly reduces the risk of spoilage in corn silages at a farm level, in both temperate and tropical environments. If the feed-out rate is lower than $150 \mathrm{~kg}$ of silage $/ \mathrm{m}^{2}$ per day, integrated management strategies should be introduced to avoid the presence of aerobically deteriorated parts on the silo face.

\section{ACKNOWLEDGMENTS}

The authors declare no conflict of interest. Mention of trade names or commercial products in this article is solely for the purpose of providing specific information and does not imply either recommendation or endorsement by the University of Turin, Italy, or by the University of Lavras, Brazil. The Italian survey was funded by Internal funds of the University of Turin, Italy. The authors thank the National Council for Scientific and Technological Development (CNPq; Brasília, Brazil), and the Coordination for the Improvement of Higher Education Personnel (CAPES; Brasília, Brazil) for their financial support and for providing scholarships. The authors thank Serenella Piano and Manuela Casale (DISAFA-University of Turin, Italy) for their help in the chemical and microbiological analyses.

\section{REFERENCES}

Allen, M. S., J. G. Coors, and G. W. Roth. 2003. Corn silage. Pages 547-608 in Silage Science and Technology. Vol. 42. D. R. Buxton, R. E. Muck, and J. H. Harrison, ed. American Society of Agronomy, Crop Science Society.

AOAC International. 2005. Official Methods of Analysis. 18th ed. AOAC International.

Bernardes, T. F., L. P. Daniel, A. T. Adesogan, T. A. McAllister, P. Drouin, L. Nussio, P. Huhtanen, G. F. Tremblay, G. Bélanger, and Y. Cai. 2018. Silage review: Unique challenges of silages made in hot and cold regions. J. Dairy Sci. 101:4001-4019. https://doi.org/ 10.3168/jds.2017-13703.

Bernardes, T. F., and A. C. do Rêgo. 2014. Study on the practices of silage production and utilization on Brazilian dairy farms. J. Dairy Sci. 97:1852-1861. https://doi.org/10.3168/jds.2013-7181.

Bernardes, T. F., J. R. S. Gervásio, G. De Morais, and D. R. Casagrande. 2019. Technical note: A comparison of methods to determine pH in silages. J. Dairy Sci. 102:9039-9042. https://doi.org/ 10.3168/jds.2019-16553.

Borreani, G., P. Dolci, E. Tabacco, and L. Cocolin. 2013. Aerobic deterioration stimulates outgrowth of spore-forming Paenibacillus in corn silage stored under oxygen-barrier or polyethylene films. J. Dairy Sci. 96:5206-5216. https://doi.org/10.3168/jds.2013-6649.

Borreani, G., F. Ferrero, D. Nucera, M. Casale, S. Piano, and E. Tabacco. 2019. Dairy farm management practices and the risk of contamination of tank milk from Clostridium spp. and Paenibacillus spp. spores in silage, total mixed ration, dairy cow feces and raw milk. J. Dairy Sci. 102:8273-8289. https://doi.org/10.3168/ jds.2019-16462.

Borreani, G., and E. Tabacco. 2010. The relationship of silage temperature with the microbiological status of the face of corn silage bunkers. J. Dairy Sci. 93:2620-2629. https://doi.org/10.3168/jds .2009-2919.

Borreani, G., and E. Tabacco. 2012. Effect of silo management factors on aerobic stability and extent of spoilage in farm maize silages. Pages 71-72 in Proc. 16th Int. Silage Conf. K. Kuoppala, M. Rin- 
nie, and A. Vanhatalo, ed. University of Helsinki and MTT Agrifood Research Finland.

Borreani, G., E. Tabacco, R. J. Schmidt, B. J. Holmes, and R. E. Muck. 2018. Silage review: Factors affecting dry matter and quality losses in silages. J. Dairy Sci. 101:3952-3979. https://doi.org/ $10.3168 /$ jds.2017-13837.

Canale, A., M. E. Valente, and A. Ciotti. 1984. Determination of volatile carboxylic acids (C1-C5) and lactic acid in aqueous acid extracts of silage by high performance liquid chromatography. J. Sci. Food Agric. 35:1178-1182. https://doi.org/10.1002/jsfa .2740351106 .

Comino, L., E. Tabacco, F. Righi, A. Revello-Chion, A. Quarantelli, and G. Borreani. 2014. Effects of an inoculant containing a $\mathrm{Lac}$ tobacillus buchneri that produces ferulate-esterase on fermentation products, aerobic stability, and fibre digestibility of maize silage harvested at different stages of maturity. Anim. Feed Sci. Technol. 198:94-106. https://doi.org/10.1016/j.anifeedsci.2014.10.001.

D'Amours, L., and P. Savoie. 2005. Density profile of corn silage in bunker silos. Can. Biosyst. Eng. 47:2.21-2.28.

Davies, D. R., A. L. Thomson, and G. Borreani. 2018. New technologies to monitor and improve silage quality from field to feed-out. Pages 438-450 in Proc. 18th Int. Silage Conf. K. Gerlach and K.H. Südekum ed. University of Bonn.

De Oliveira, I., E. Tabacco, F. Ferrero, G. Borreani, and T. F. Bernardes. 2018. A new approach to assess feed-out rate in maize silage bunker. Pages 454-455 in Proc. 18th Int. Silage Conf. K. Gerlach and K.-H. Südekum, ed. University of Bonn.

Drouin, P., J. Tremblay, J. Renaud, and E. Apper. 2021. Microbiota succession during aerobic stability of maize silage inoculated with Lentilactobacillus buchneri NCIMB 40788 and Lentilactobacillus hilgardii CNCM-I-4785. MicrobiologyOpen 10:e1153. https://doi .org/10.1002/mbo3.1153.

Ferraretto, L. F., and R. D. Shaver. 2012. Meta-analysis: Effect of corn silage harvest practices on intake, digestion, and milk production by dairy cows. Prof. Anim. Sci. 28:141-149. https://doi.org/ 10.15232/S1080-7446(15)30334-X.

Ferrero, F., S. Prencipe, D. Spadaro, M. L. Gullino, L. Cavallarin, S. Piano, E. Tabacco, and G. Borreani. 2019. Increase in aflatoxins due to Aspergillus section Flavi multiplication during the aerobic deterioration of corn silage treated with different bacteria inocula. J. Dairy Sci. 102:1176-1193. https://doi.org/10.3168/jds .2018-15468.

Gervásio, G., I. De Oliveira, E. Tabacco, F. Ferrero, G. Borreani, and T. F. Bernardes. 2018. A pH index as a method to identify aerobic deterioration in farm maize silage. Pages 456-457 in Proc. 18th Int. Silage Conf. K. Gerlach and K.-H. Südekum, ed. University of Bonn, Bonn, Germany.

Holmes, B. J., and R. E. Muck. 2007. Packing bunkers and piles to maximize forage preservation. Pages 1-9 in Proc. 6th Int. Dairy Housing Conf. ASABE. https://doi.org/https://doi.org/10.13031/ 2013.22815.

Johnson, L., J. H. Harrison, C. Hunt, K. Shinners, C. G. Doggett, and D. Sapienza. 1999. Nutritive value of corn silage as affected by maturity and mechanical processing: A contemporary review. J. Dairy Sci. 82:2813-2825. https://doi.org/10.3168/jds.S0022 -0302(99)75540-2.
Mahanna, B., and L. E. Chase. 2003. Practical applications and solutions to silage problems. Pages $855-895$ in Silage Science and Technology. Vol. 42. D. R. Buxton, R. E. Muck, and J. H. Harrison ed. Am. Soc. Agron., Crop Sci. Soc. Am., and Soil Sci. Soc. Am.

Ogunade, I. M., C. Martinez-Tuppia, O. C. M. Queiroz, Y. Jiang, P. Drouin, F. Wu, D. Vyas, and A. T. Adesogan. 2018. Silage review: Mycotoxins in silage: Occurrence, effects, prevention, and mitigation. J. Dairy Sci. 101:4034-4059. https://doi.org/10.3168/ jds.2017-13788.

Opsi, F., R. Fortina, G. Borreani, E. Tabacco, and S. López. 2013. Influence of cultivar, sowing date and maturity at harvest on yield, digestibility, rumen fermentation kinetics and estimated feeding value of maize silage. J. Agric. Sci. 151:740-753. https://doi.org/ 10.1017/S0021859612000925.

Pahlow, G., R. E. Muck, F. Driehuis, and S. J. W. H. Oude Elferink. 2003. Microbiology of ensiling. Pages 31-94 in Silage Science and Technology. Vol. 42. D. R. Buxton, R. E. Muck, and J. H. Harrison, ed. Am. Soc. Agron., Crop Sci. Soc. Am., and Soil Sci. Soc. Am.

Porter, M. G., and R. S. Murray. 2001. The volatility of components of grass silage on oven drying and the inter-relationship between drymatter content estimated by different analytical methods. Grass Forage Sci. 56:405-411. https://doi.org/10.1046/j.1365-2494.2001 $.00292 . \mathrm{x}$.

Ruppel, K. A., R. E. Pitt, L. E. Chase, and D. M. Galton. 1995. Bunker silo management and its relationship to forage preservation on dairy farms. J. Dairy Sci. 78:141-153. https://doi.org/10.3168/jds .S0022-0302(95)76624-3.

Santos, A. O., G. S. Dias Junior, M. N. Pereira, R. F. Schwan, and C. L. S. Ávila. 2020. A survey of whole-plant corn silages from Minas Gerais dairy farms. Sci. Agrar. 77:e20180080. https://doi.org/10 .1590/1678-992x-2018-0080.

Van Soest, P. J., J. B. Robertson, and B. A. Lewis. 1991. Methods of dietary fiber, neutral detergent fiber, and nonstarch polysaccharides in relation to animal nutrition. J. Dairy Sci. 74:3583-3597. https://doi.org/10.3168/jds.S0022-0302(91)78551-2.

Vissers, M. M. M., F. Driehuis, M. C. te Giffel, P. De Jong, and J. M. G. Lankveld. 2007. Concentrations of butyric acid bacteria spores in silage and relationships with aerobic deterioration. J. Dairy Sci. 90:928-936. https://doi.org/10.3168/jds.S0022-0302(07)71576-X.

Wilkinson, J. M., and D. R. Davies. 2013. The aerobic stability of silage: Key findings and recent developments. Grass Forage Sci. 68:1-19. https://doi.org/10.1111/j.1365-2494.2012.00891.x.

Wilkinson, J. M., and M. I. Toivonen. 2003. World Silage: A Survey of Forage Conservation Around the World. Chalcombe Publications.

\section{ORCIDS}

T. F. Bernardes ๑ https://orcid.org/0000-0002-2479-922X

F. Ferrero (ㄴ) https://orcid.org/0000-0002-9551-0796

E. Tabacco $\odot$ https://orcid.org/0000-0002-5021-5486

G. Borreani $\odot$ https://orcid.org/0000-0002-7726-4173 